\title{
The Contextual Effect of Social Norm on Early Marriage Among Young Women in Lampung: A Multilevel Analysis Evidence
}

\author{
Nurhayati Agtikasari'), RB. Soemanto'), Bhisma Murti1) \\ 1)Masters Program in Public Heath, Universitas Sebelas Maret \\ 2)Faculty of Social and Political Sciences, Universitas Sebelas Maret
}

\begin{abstract}
Background: Early marriage is driven by poverty and has many effects on girls' health: increased risk for sexually transmitted diseases, cervical cancer, malaria, death during childbirth, and obstetric fistulas. Girls' offspring are also at increased risk for premature birth and death as neonates, infants, or children. This study aimed to investigate the contextual effect of social norm on early marriage among young women in Lampung, using multilevel analysis.

Subjects and Method: This was a case control study conducted in Metro, East Lampung, Indonesia, from May to June 2018. A sample of 200 women was selected by random sampling, comprising 50 women who got married at under 21 years of age and 150 women who got married at $\geq 21$ years of age. The dependent variable was early marriage. The dependent variables were self efficacy, family income, family support, informational access at level 1 in multilevel analysis. Social norm were placed at level 2 in multilevel analysis. The data were collected by questionnaire and analyzed by multilevel analysis.

Results: Marital age was postpone by self-efficacy $(b=-1.93 ; 95 \% \mathrm{CI}=-2.81$ to $-1.05 ; \mathrm{p}<0.001$ ), high family income $(b=-1.20 ; 95 \% \mathrm{CI}=-2.07$ to $-0.33 ; \mathrm{p}=0.007)$, strong family support $(\mathrm{b}=-1.27$; $95 \% \mathrm{CI}=-2.35$ to $-0.19 ; \mathrm{p}=0.021)$, and access to positive information $(\mathrm{b}=-1.06 ; 95 \% \mathrm{CI}=-2.08$ to $0.04 ; \mathrm{p}=0.042$ ). Social norm had a contextual effect on marital age postponement with $\mathrm{ICC}=$ $14.56 \%$.

Conclusion:Marital age is reduced by strong self-efficacy, high family income, strong family support, and access to positive information. Social norm has a contextual effect on marital age postponement.
\end{abstract}

Keywords: marital age postponement, self-efficacy, family income, family support, access to positive information, social norm

\section{Correspondence:}

Nurhayati Agtikasari. Masters Program in Public Heath, Universitas Sebelas Maret, Jl. Ir. Sutami 36 A, Surakarta 57126, Central Java. Email: agtikasari2@gmail.com.

Mobile: +6282185965148 .

\section{BACKGROUND}

The fifth goal of the Sustainable Development Goals (SDG) is to end the violence against women and girls and the dangerous practices such as early marriage. The 2017 SDGs report on gender equality showed that women in Indonesia are more likely to marry before 18 years compared to other women in the East Asia and Pacific region. Based on national data, one out of ten women aged 20-24 were married before 18 years in 2015 (Indonesian Ministry of National Development Planning and the United Nations Children's Fund, 2017)

The law governing the minimum marriage limit in Indonesia is in Article 6 paragraph 2 of Law No. 1 of 1974 also states that for a marriage, someone under the age of 21 must obtain permission from both parents (Republic of Indonesia, 1974).

The determinants of early marriage can be studied by behavioral theory, one of 
them is social cognitive theory. Social cognitive theory consists of individual internal factors and external factors (Bandura, 2002). Individual internal factors that can influence the likelihood of early marriage include knowledge, self-efficacy and attitudes, while external factors are family income, family support, access to information, shelter, and social norms of society (Sulaeman, 2016) (Central Board Statistics, 2016) (World Health Organization, 2016).

The data from Susenas (2012) show that the number of women aged 20-24 who were married before 18 years was $1,348,886$ children, with an average of 3,695 children per day. In 2015, Lampung Province was ranked sixth (18.3\%) of all provinces in Sumatra Island based on the percentage of married women before 18 years among women aged 20-24 years who were married. The number of young marriage couples who conduct trials to get married dispensation in the Lampung Provincial Religion High Court has increased by $41.7 \%$ (102 pairs) from 71 pairs in 2015 (Central Statistics Agency, 2016) (High Religion Court of Bandar Lampung, 2016).

The practice of getting married at an early age can trigger some negative effects on young couples. The impacts to be obtained for married couples of early age include loss of opportunity to continue their education to a higher level, the likelihood of domestic violence by their husbands towards their wives will be greater than those of married couples in adulthood, and limited use of maternal health services including during pregnancy to control contraceptive use. (Delprato et al, 2015) (Godha et al, 2013) (Nasrullah et al, 2014).

Divorce is another consequence of early marriage. The number of divorce cases in Indonesia was $346,480,324,247$ and 347,256 in 2012, 2013 and 2015, while in Lampung province, there were 5,447,
4894 and 6667. Divorce case data on the Annual Report of the National Commission on Violence shows that there were 305.535 total of cases based on the religious courts.

The highest cause of the record was that there was no harmony of $32 \%(97,418)$ and married at a young age also had an influence of $0.4 \%(1,131)$. Divorce cases also relate to the incidence of violence against couples in the household. The number of domestic violence cases in Indonesia in 2015 is 11,207 in total, while Lampung Province had a total of 469 domestic violence cases (Indonesian BPS, 2018) (Indonesian National Commission on Women, 2016).

In this study, the researchers sought to determine the effects on the individual level and contextual influence on village on the possibility of early marriage in Lampung Province, Indonesia.

\section{SUBJECTS AND METHOD}

\section{Study Design}

This was an analytic observational study with a case control design. The study was conducted in Metro City and East Lampung Regency, Indonesia, from May 2018 to June 2018.

\section{Population and Samples}

The target population in this study were married women. The source population is women who have been married for the last 10 years in Metro City and East Lampung Regency. A sample of 200 married women was selected by fixed disease sampling.

\section{Study Variables}

The dependent variable was early marriage. The independent variables were selfefficacy, family income, family support, access to information, and social norm.

\section{Operational Definition of Variables}

Early marriage was described as women whose first marriage age under the age of 21 and legally married by country and 
religion, as well as having marriage documents such as marriage books or documents from civil records. The measurement scale was categorical, coded o for no and 1 for yes.

Self-efficacy was defined as the respondents' beliefs and positive abilities to control married behavior under the age of 21 years. The data were collected by questionnaire. The measurement scale was continuous, but for the purpose of data analysis, it was transformed into dichotomous, coded o for weak and 1 for strong.

Family support was defined as support given in the form of consent to delay the age of marriage of the respondent up to $\geq 21$ years old. Assessment of family support includes aspects of assessment, instrumental, and information supports. The data were collected by questionnaire. The measurement scale was continuous, but for the purpose of data analysis, it was transformed into dichotomous, coded o for weak and 1 for strong

Information access was defined as the respondent's exposure to the media as a source of information about early marriage including the minimum legal age for marriage, factors to impact before marriage. The data were collected by questionnaire. The measurement scale was continuous, but for the purpose of data analysis, it was transformed into dichotomous, coded $\mathrm{o}$ for weak and 1 for strong.

The social norm defined as the beliefs and regulations of the village community which are known through community leaders in the region about early marriage that applies in the neighborhood where the respondent lives. The data were collected by questionnaire. The measurement scale was continuous, but for the purpose of data analysis, it was transformed into dichotomous, coded $\mathrm{o}$ for negative and 1 for positive.

\section{Data Analysis}

Univariate analysis was conducted to see the frequency distribution and percentage characteristics of subjects. Bivariate analysis was performed to study the relationship between early marriage occurrence and the independent variable was conducted using chi-square test and odds ratio calculation (OR) with confidence level (CI) of $95 \%$. Then multivariate analysis was performed by a multilevel logistic regression run on Stata 13.

\section{Research Ethics}

The research ethics include informed consent, anonymity, confidentiality, and ethical clearance. The ethical clearance in this study was conducted at the Commission of Medical Research Ethics, Faculty of Medicine, Universitas Sebelas Maret, Surakarta, Central Java, with no. Ethical Feasibility: 51 / UN27.6 / KEPK / 2018.

\section{RESULTS}

\section{Sample Characteristics}

The frequency distribution of the characteristics of the study subjects is described in Table 1.

Table 1 shows that as many as 149 women (74.5\%) had education level $\geq$ senior high school. Most of the paternal education $\geq$ senior high school with a total of 147 people $(73.5 \%)$ and maternal education $\geq$ senior high school 157 (78.5\%).

\section{Bivariate Analysis on the Deter- minants of Early Marriage}

Bivariate analysis was conducted to examine relationship of self efficacy, family income, family support, and information access, on the incidence of early marriage. The result of bivariate analysis was showed in Table 2.

Table 2 shows that self-efficacy was associated with early marriage. Strong selfefficacy reduced the likelihood of early 
marriage $(\mathrm{OR}=0.10 ; 95 \% \mathrm{CI}=0.10$ to 0.41 ; $\mathrm{p}<0.001)$.

Family income was associated with early marriage. High family income reduced the likelihood of early marriage $(\mathrm{OR}=0.28 ; 95 \% \quad \mathrm{CI}=0.14$ to 0.55 ; $\mathrm{p}<0.001)$.

Family support was associated with early marriage. Strong family support reduced the likelihood of early marriage $(\mathrm{OR}=0.17 ; 95 \% \quad \mathrm{CI}=0.08$ to 0.36 ; $\mathrm{p}<0.001)$.

Access to information was associated with early marriage. Good access to information reduced the likelihood of early marriage $(\mathrm{OR}=0.30 ; 95 \% \mathrm{CI}=0.15$ to 0.61 ; $\mathrm{p}=0.001)$.
Table 1. Sample characteristics

\begin{tabular}{|c|c|c|}
\hline Characteristics & $\mathbf{N}$ & $\%$ \\
\hline \multicolumn{3}{|l|}{ Age at married } \\
\hline$<21$ years old & 50 & 25 \\
\hline$\geq 21$ years old & 150 & 75 \\
\hline \multicolumn{3}{|l|}{ Education } \\
\hline$<$ Senior high school & 51 & $25 \cdot 5$ \\
\hline$\geq$ Senior high school & 149 & 74.5 \\
\hline \multicolumn{3}{|l|}{ Paternal Education } \\
\hline$<$ Senior high school & 53 & 26.5 \\
\hline$\geq$ Senior high school & 147 & $73 \cdot 5$ \\
\hline \multicolumn{3}{|l|}{ Maternal Education } \\
\hline$<$ Senior high school & 43 & 21.5 \\
\hline$\geq$ Senior high school & 157 & 78.5 \\
\hline
\end{tabular}

Table 2. The results of bivariate analysis on the early marriage determinants

\begin{tabular}{|c|c|c|c|c|c|c|c|c|c|}
\hline \multirow{3}{*}{ Variable } & \multicolumn{4}{|c|}{ Early Marriage } & \multirow{2}{*}{\multicolumn{2}{|c|}{ Total }} & \multirow{3}{*}{$\mathbf{O R}$} & \multirow{3}{*}{$95 \% \mathrm{CI}$} & \multirow{3}{*}{$\mathbf{p}$} \\
\hline & \multicolumn{2}{|c|}{ No } & \multicolumn{2}{|c|}{ Yes } & & & & & \\
\hline & $\mathbf{N}$ & $\%$ & $\mathbf{N}$ & $\%$ & $\mathbf{N}$ & $\%$ & & & \\
\hline \multicolumn{10}{|l|}{ Self Efficacy } \\
\hline Weak (score < 2) & 55 & 59.8 & 37 & 40.2 & 92 & 100 & \multirow[t]{2}{*}{0.20} & \multirow{3}{*}{0.10 to 0.41} & \multirow{3}{*}{$<0.001$} \\
\hline Strong (score $\geq 2$ ) & 95 & 88 & 13 & 12 & 108 & 100 & & & \\
\hline \multicolumn{8}{|l|}{ Family Income } & & \\
\hline Low $<$ Rp 1,500,000 & 59 & 62.8 & 35 & 37.2 & 94 & 100 & \multirow[t]{2}{*}{0.28} & \multirow{3}{*}{0.14 to 0.55} & \multirow{2}{*}{$<0.001$} \\
\hline High $\geq$ Rp 1,500,000 & 91 & 85.8 & 15 & 14.2 & 106 & 100 & & & \\
\hline \multicolumn{9}{|l|}{ Family Support } & \\
\hline Weak (score <2) & 15 & 42.9 & 20 & 57.1 & 35 & 100 & \multirow[t]{2}{*}{0.17} & \multirow{3}{*}{0.08 to 0.36} & \multirow{3}{*}{$<0.001$} \\
\hline Strong (score $\geq 2$ ) & 135 & 81.8 & 30 & 18.2 & 165 & 100 & & & \\
\hline \multicolumn{8}{|c|}{ Informational Access } & & \\
\hline Poor & 25 & 55.6 & 20 & 44.4 & 45 & 100 & 0.30 & 0.15 to 0.61 & 0.001 \\
\hline Good & 125 & 80.6 & 30 & 19.4 & 155 & 100 & & 0.1500 .01 & 0.001 \\
\hline
\end{tabular}

\section{The Results of Multilevel Analysis}

The results of multilevel analysis were shown in Table 3. Table 3 showed that selfefficacy was negatively associated with early marriage. Strong self-efficacy decreased the likelihood of early marriage $(b=-1.93 ; 95 \%$ $\mathrm{CI}=-2.81$ to $-1.05 ; \mathrm{p}<0.001$ ),

Family income was negatively associated with early marriage $(b=-1.20 ; 95 \%$ $\mathrm{CI}=-2.08$ to $-0.33 ; \mathrm{p}=0.007$ ). High family income decreased the likelihood of early marriage $(b=-1.27 ; 95 \% \mathrm{CI}=-2.35$ to -0.19 ; $\mathrm{p}=0.021)$.

Access to information was negatively associated with early marriage. Good access to information decreased the likelihood of early marriage $(b=-1.06 ; 95 \% \mathrm{CI}=-2.07$ to $0.04 ; \mathrm{p}=0.042$ ).

The results of multilevel data analysis in this study showed that social norm had contextual effect on the incidence of early marriage with $\mathrm{ICC}=14.56 \%$. 
Agtikasari et al./ The Contextual Effect of Social Norm on Early Marriage

Table 3. The results of multilevel logistic analysis on the determinants of early marriage

\begin{tabular}{|c|c|c|c|c|}
\hline \multirow[b]{2}{*}{ Early Marriage } & \multirow[b]{2}{*}{ b } & \multicolumn{2}{|c|}{ 95\% CI } & \multirow[b]{2}{*}{$\mathbf{p}$} \\
\hline & & Lower limit & $\begin{array}{c}\text { Upper } \\
\text { limit }\end{array}$ & \\
\hline \multicolumn{5}{|l|}{ Fixed Effect } \\
\hline Self Efficacy & -1.93 & -2.81 & -1.05 & $<0.001$ \\
\hline Family Income & -1.20 & -2.08 & -0.33 & 0.007 \\
\hline Family Support & -1.27 & -2.35 & -0.19 & 0.021 \\
\hline Informational Access & -1.06 & -2.07 & -0.04 & 0.042 \\
\hline Constant & 2.07 & 0.74 & 3.39 & \\
\hline \multicolumn{5}{|l|}{ Random Effect } \\
\hline \multicolumn{5}{|l|}{ Village and Sub-district } \\
\hline Var (Constant) & 0.56 & 0.06 & $5 \cdot 32$ & \\
\hline Observation Score $=200$ & & & & \\
\hline Social Capital Group Score $=8$ & & & & \\
\hline Log likelihood $=-84.73$ & & & & \\
\hline LR test vs. Logistic Regression, $p=0.092$ & & & & \\
\hline $\mathrm{ICC}=14.56 \%$ & & 0.02 & 0.62 & \\
\hline
\end{tabular}

\section{DISCUSSION}

\section{The effect of self efficacy on the} incidence of early marriage

The result of analysis showed that there was an association between self efficacy and early marriage. Women with strong selfefficacy were less likely to have early marriage than those with weak self-efficacy.

The result of a study entitled "Predictors of Intention to Marriage Based on Theory of Planned Behavior Among University Students In Iran" showed that perceived behavioral control on a model of planned behavioral theory called selfefficacy in cognitive theory has the likelihood to have the intention to get married (Akhondali et al, 2015).

Decision making was an important part of doing a behavior. People who already have education and decent occupations were more likely to control the intention to get married (Seyfzadeh et al, 2014).

High self efficacy has an effect on early marriage. Beliefs in delaying early marriage behavior could occur in women who have high self-efficacy.

\section{The effect of family income on the incidence of early marriage}

The result of analysis showed that there was an association between family income and early marriage. Women with high family income were less likely to married at an early age than those with low income families.

Parental income has a direct effect on the incidence of early marriage. High parental income would reduce the likelihood of their daughters to get married at young age (Wijayati et al., 2017).

A study entitled "Determinants of Early Marriage among Female Children in Sinan District, Northwest Ethiopia" showed that families with low monthly incomes were 2.5 times more likely to have early marriages for their daughters than those with high monthly incomes (Workineh et al, 2015).

Child marriage was related to a number of socio-economic characteristics, including family income. Daughters who were married would live separately from their families and live with their husbands, therefore, it would decrease the economic burden of their families. Inadequate 
income would also affect children's educational status which was low, resulting the children to have early marriage (Hotchkiss et al, 2016; Bhanji and Punjani, 2014).

\section{The effect of family support on early marriage}

The result of analysis showed that there was an association between family support and early marriage. Women with strong family support to postpone marriage until $\geq 21$ years old were less likely to have early marriage than those who have weak family support.

Local culture of early marriage has an effect on early marriage. The majority of teenagers thought that marriage before 20 years old was normal. Adolescents in groups who get married at an early age were dominated by families who supported early marriage (Husna et al., 2016).

A study by Montazeri et al. (2016), entitled "Determinants of Early Marriage from Married Girls' Perspectives in Iranian Setting" showed thatmarriage for girls was a process of accepting new roles and responsibilities. The process was the reason for them to postpone marriage, but the decision to get married was also influenced by several things including completing the education and family factors. Family was a determinant factor in decision making for children to marry, because families have a system of roles and norms which were obeyed by the daughters.

A strong form of family support was a basic factor in making the decisions for marriage. Family norms about abelief to postpone marriage until $\geq 21$ years old provide the possibility of influencing children's mindset and decision to have early marriage.

\section{The effect of informational access on early marriage}

This study also showed that there was an association between informational access on early marriage. Women who have good access to information about early marriage were less likely to have early marriage.

A study entitled "Determinants of Early Marriage in Rajshahi, Bangladesh" showed that access to information media has an effect on early marriage. Women who have access to media such as listening to the radio, watching television, and other media that provide information about the dangers of early marriage were less likely to have early marriage than those who never get the information (Roy, 2008).

A study showed that the majority of people who have done early marriage did not know the legal minimum age for marriage. Another study conducted among teenagers in Bangladesh revealed similar results that the majority of those who get married at an early age did not have good information about the legal age for marriage (Pandya and Bhanderi, 2015).

\section{The effect of village and sub- district levels on early marriage}

The results showed that the variation of early marriage by $14.56 \%$ was determined by the variables at the village and subdistrict level about social norms of society, so it was important to be noted.

A study showed that an enhancement in the number of early marriages was due to exceptions with certain conditions on the law regulation about the age of marriage. The impact of the exceptions and the existence of social norms in society resulted in ineffective law regulation about the age limit to get married. Customary regulation in some countries which made an exception to the minimum age limit for marriage would allow the girls to get married before the age of 18 with the parental permission (McCleary-Sills et al, 2015; Vogelstein, 2013).

Culture has a direct effect on the incidence of early marriage. Community 
culture that supported early marriage has a greater likelihood of early marriage among adolescents in their neighborhood (Wijayati et al., 2017).

Another study about social norms on early marriage which was done by Workineh et al. (2015), showed that in some communities, marriage among children has been a tradition long ago, because people have a negative view toward women who postpone their marriages. Asking the girls to get married early was a solution to ensure family socio-economic status. Virgin status in women was an important value that must be guarded for the honor of the family, therefore, early marriage was also used as a primary choice to avoid prohibited sexual acts rather than improving the status of children's education.

From the results of this study, it can be concluded that early marriage was negatively affected by high self-efficacy, high family income, strong family support, and good informational access and $14.56 \%$ of early marriage variations were affected by social norms of society at each village level.

\section{CONFLICT OF INTEREST}

None declared

\begin{tabular}{l}
\hline REFERENCES \\
\hline Akhondali Z, Dianat M, Radan M (2015). \\
Predictors of intention to marriage \\
based on theory of planned behavior \\
among university students in Iran. \\
Electronic Physician, 7(1): 971-976. \\
https://doi.org/10.14661/2015.971- \\
976
\end{tabular}

Badan Pusat Statistik (2016). Kemajuan yang tertunda: analisis data perkawinan usia anak di Indonesia. Jakarta.

Bandura A (2002). Social cognitive theory in cultural context. Applied Psycho- logy, 51(2): 269-290. https://doi.org/10.1111/1464-0597.00092.

Bhanji SM, Punjani NS (2014). Determinants of Child (Early) Marriages among Young Girls: A Public Health Issue. J Women's Health Care, 3(161), 2167-2169. https://doi.org/http://dx.doi.org/10.4172/2167-0420.1000161.

BPS Indonesia (2018). Nikah, Talak dan Cerai, serta Rujuk, 2012-2015. Retrieved from https://www.bps.go.id/linkTableDinamis/view/id/893

Delprato M, Akyeampong K, Sabates R, Hernandez-Fernandez J (2015). On the impact of early marriage on schooling outcomes in Sub-Saharan Africa and South West Asia. International Journal of Educational Development, 44, 42-55. https://doi.org/10.1016/j.ijedudev.2015.06.001

Godha D, Hotchkiss DR, Gage AJ (2013). Association between child marriage and reproductive health outcomes and service utilization: A multicountry study from south asia. Journal of Adolescent Health, 52(5), 552558. https://doi.org/10.1016/j.jadohealth.2013.01.021

Hotchkiss DR, Godha D, Gage AJ, Cappa C (2016). Risk factors associated with the practice of child marriage among Roma girls in Serbia Health and human rights of marginalized populations. BMC International Health and Human Rights, 16(1), 1-10. https://doi.org/10.1186/s12914-016oo81-3

Husna N, Demartoto A, Respati S (2016). Factors Associated with Early Marriage in Sleman, Yogyakarta. Journal of Health Promotion and Behavior, 1(2), 87-98. Retrieved from https://doi.org/10.26911/thejhpb.2016.01.02.04

Indonesia Ministry of National Develop- 
ment Planning and the United Nations Children's Fund. (2017). SDG Baseline report on children in Indonesia. Jakarta.

Komnas Perempuan Indonesia (2016). Kekerasan terhadap perempuan meluas: Negara Urgen hadir hentikan kekerasan terhadap perempuan di ranah domestik, komunitas dan negara. Jakarta.

McCleary-Sills J, Hanmer L, Parsons J, Klugman J (2015). Child marriage: a critical barrier to girls' schooling and gender equality in education. Review of Faith and International Affairs, 13(3), 69-80. https://doi.org/10.1080/15570274.2015.1075755.

Montazeri S, Gharacheh M, Mohammadi N, Alaghband Rad J, Ardabili EH (2016). Determinants of early marriage from married girls' perspectives in Iranian setting: a qualitative study. Journal of Environmental and Public Health, 2016. https://doi.org/10.1155/2016/8615929.

Nasrullah M, Zakar R, Zakar MZ (2014). Child marriage and its associations with controlling behaviors and spousal violence against adolescent and young women in Pakistan. Journal of Adolescent Health, 55(6), 804-809. https://doi.org/10.1016/j.jadohealth. 2014.06.013.

Pandya YP, Bhanderi DJ (2015). An epidemiological study of child marriages in a rural community of Gujarat. Indian J Community Med, 40(4), 246-251.

Pengadilan Tinggi Agama Bandar Lam- pung. (2016).

Republik Indonesia (1974). Undangundang Republik Indonesia Nomor 1 tahun 1974 tentang perkawinan. lembaran negara republik Indonesia 1974. Jakarta: Sekretariat Negara. Retrieved from http://luk.staff.ugm.ac.id/atur/UU1-1974Perkawinan.pdf

Roy TK (2008). Determinants of early marriage in Rajshahi, Bangladesh. Pakistan Journal of Social Science, 5(6), 606-611.

Sulaeman ES (2016). Pembelajaran model dan teori perilaku kesehatan konsep dan aplikasi.

Vogelstein R (2013). Ending child marriage: how elevating the status of girls advances U.S. Foreign Policy Objectives.

Wijayati NA, Soemanto RB, Pamungkasari EP (2017). Socioeconomic and cultural determinants of early marriage in Ngawi, East Java: Application of PRECEDE-PROCEED Model. Journal of Health Promotion and Behaviour, 2(4), 302-312. https://doi.org/10.26911/thejhpb.2016.02.04.02Â

Workineh S, Kibretb GD, Degu G (2015). Determinants of early marriage among female children in Sinan District, Northwest Ethiopia. Journal, Health Science, 9(6), 1-7.

World Health Organization (2016). Child, early and forced marriage legislation in 37 Asia-Pacific countries. Retrieved from http://www.who.int/reproductivehealth/publications/gender_rights/cefm-asia-pacific/en/ 